\title{
Pós-Graduação Stricto Sensu em Anestesiologia: Experiência de Dez Anos na UNESP *
}

\section{Strictu Sensu Post-Graduation in Anesthesiology: Experience of Ten Years at Universidade Estadual Paulista}

José Reinaldo Cerqueira Braz, TSA ${ }^{1}$; Pedro Thadeu Galvão Vianna, TSA ${ }^{1}$; Yara Marcondes Machado Castiglia, TSA ${ }^{1}$; Luiz Antonio Vane, TSA ${ }^{1}$; Flávio Massone ${ }^{2}$; Lino Lemonica, TSA ${ }^{3}$; Gladys Bastos de Castro ${ }^{4}$

\begin{abstract}
RESUMO
Braz JRC, Vianna PTG, Castiglia YMM, Vane LA, Massone F, Lemonica L, Castro GB - Pós-Graduação Stricto Sensu em Anestesiologia: Experiência de Dez Anos na UNESP
\end{abstract}

JUSTIFICATIVA E OBJETIVOS: O número de Programas de Pós-Graduação em Anestesiologia stricto sensu existente no país ainda é muito pequeno. Com a finalidade de incentivar a pós-graduação em Anestesiologia no Brasil, é apresentada a experiência acumulada em dez anos de atividades do programa da Universidade Estadual Paulista (UNESP).

CONTEÚDO: O Programa de Pós-Graduação em Anestesiologia stricto sensu da UNESP foi credenciado pela CAPES, desde a sua criação em 1994, nos Cursos de Mestrado e Doutorado. O Programa é desenvolvido em três Áreas de Concentração: Risco e Proteção de Órgãos e Sistemas em Anestesia e Cirurgia; Qualidade e Segurança em Anestesiologia; e Modelos Clínicos e Experimentais em Terapia Antálgica, com as suas respectivas linhas de pesquisa, em número de 14. O número de alunos regulares do Programa é compatível com o número de orientadores (12), com proporção média de três alunos por orientador. Desde o seu início até setembro de 2004, ocorreram 45 Dissertações de Mestrado e 24 de Doutorado, perfazendo 69 defesas, a maioria com bolsas e financiamentos de Órgãos de Fomento à Pesquisa. Após a conclusão do doutorado, $65 \%$ dos alunos têm atividade de docência e pesquisa em instituições públicas e privadas do ensino universitário do país. A maioria das publicações do programa tem sido realizada em revistas nacionais com Qualis A, com menor número de publicações em revistas internacionais Qualis A ou B. O programa recebeu da CAPES o conceito 4,0 numa escala de 1 a 7 , em suas três últimas avaliações.

CONCLUSÕES: O programa tem se desenvolvido muito bem nos 10 anos de sua existência, alcançando os principais

\footnotetext{
* Recebido do (Received from) CET/SBA da UNESP - Universidade Estadual Paulista, Faculdade de Medicina de Botucatu (FMB) - SP

1. Professor Titular da UNESP, Departamento de Anestesiologia da FMB

2. Professor Titular Aposentado da UNESP, Departamento de Cirurgia e Anestesiologia Veterinária, Faculdade de Medicina Veterinária e Zootecnia (FMVZ)

3. Professor Assistente Doutor da UNESP, Departamento de Anestesiologia da FMB

4. Professora Assistente Doutora Aposentada da UNESP, Departamento de Cirurgia e Anestesiologia Veterinária da FMVZ
}

Apresentado (Submitted) em 06 de outubro de 2004 Aceito (Accepted) para publicação em 03 de março de 2005

Endereço para correspondência (Correspondence to)

Prof. Dr. José Reinaldo Cerqueira Braz

Dept ${ }^{\circ}$ de Anestesiologia da FMB - UNESP

18618-970 Botucatu, SP

E-mail:jbraz@fmb.unesp.br

(C) Sociedade Brasileira de Anestesiologia, 2005 objetivos, como a formação de professores e pesquisadores na área de Anestesiologia para as instituições universitárias do país.

Unitermos: ANESTESIOLOGIA, Pós-graduação

\section{SUMMARY}

Braz JRC, Vianna PTG, Castiglia YMM, Vane LA, Massone F, Lemonica L, Castro GB - Strictu Sensu Post-Graduation in Anesthesiology: Experience of Ten Years at Universidade Estadual Paulista

BACKGROUND AND OBJECTIVES: There are still few strictu sensu Post-Graduation Programs in Anesthesiology in Brazil. Aiming at fostering post-graduation in Anesthesiology in Brazil, we present the experience of ten years at Universidade Estadual Paulista (UNESP).

CONTENTS: Strictu sensu post-graduation program in Anesthesiology - UNESP was accredited by CAPES since its beginning in 1994, for Master and Doctoral programs. The program is developed around three fields of study: Organs and Systems Risk and Protection in Anesthesia and Surgery; Quality and Safety in Anesthesiology; and Clinical and Experimental Models for Pain Therapy, with their respective 14 research lines. The number of regular students is compatible with the number of faculty advisers (12), with three students per adviser in average. From its beginning to September 2004, there were 45 Master and 24 Doctoral reports, in a total of 69 presentations, most of them with scholarships and funding granted by Research Fostering Agencies. After receiving their doctor's degree, 65\% of students dedicate themselves to teaching and researching in Brazilian public and private universities. Most studies are published in Qualis A Brazilian journals with a lower number of publications in international Qualis A or B journals. The program was scored 4.0 by CAPES, in a scale from 1 to 7 , in its three most recent evaluations.

CONCLUSIONS: The program has positively evolved throughout its 10 years of existence and major objectives have been reached, such as qualification of professors and investigators in Anesthesiology for Brazilian universities.

Key Words: ANESTHESIOLOGY: Post-graduation

\section{INTRODUÇÃO}

A longo das últimas décadas, a pós-graduação stricto sensu no Brasil adquiriu dimensão de destaque no sistema de ensino superior do país. Atualmente, o país conta com aproximadamente 2.500 programas de pós-graduação, sendo que $35 \%$ de doutorado, envolvendo em torno de cem mil estudantes e titulando cerca de 5.000 doutores por ano ${ }^{1}$.

Segundo o artigo $1^{\circ}$ da Resolução da Universidade Estadual Paulista (UNESP) n 45 de $1999^{2}$, que dispõe sobre o Regi- 
mento Geral de Pós-Graduação, a Pós-Graduação da UNESP tem por objetivo a formação de docentes, de pesquisadores e de recursos humanos especializados nos diferentes ramos do saber, bem como o desenvolvimento científico e tecnológico.

No Brasil, existem atualmente dois Programas de Pós-Graduação em Anestesiologia stricto sensu, ambos no Estado de São Paulo. O primeiro e mais antigo, da Faculdade de Medicina da Universidade de São Paulo (USP) em São Paulo e o mais recente da UNESP, na Faculdade de Medicina de Botucatu. Outros Programas de Pós-Graduação stricto sensu, geralmente da área cirúrgica, também têm linhas de pesquisa em Anestesiologia, o que permite que os anestesiologistas também possam cursar esses programas e realizar pesquisas na área da Anestesiologia.

Com o objetivo de incentivar a pós-graduação stricto sensu em Anestesiologia no Brasil, apresentar-se-á um programa de pós-graduação e a sua experiência acumulada em dez anos de atividade.

\section{PROGRAMA DE PÓS-GRADUAÇÃO EM ANESTESIOLOGIA DA UNESP}

O programa stricto sensu em Anestesiologia da UNESP, após aprovação pela Coordenação do Aperfeiçoamento de Pessoal de Nível Superior (CAPES), iniciou suas atividades em agosto de 1994, com a finalidade de formar pesquisadores e docentes na área de Anestesiologia, e está aberto a médicos e médicos veterinários, com especialização em Anestesiologia
O programa sempre teve caráter interdepartamental e interunidades no âmbito da UNESP, inicialmente pelo envolvimento do Departamento de Anestesiologia da Faculdade de Medicina de Botucatu e do Departamento de Cirurgia e Anestesiologia Veterinária da Faculdade de Medicina Veterinária e Zootecnia e, em seguida, de outros Departamentos da Faculdade de Medicina e do Instituto de Biociências de Botucatu e da Disciplina de Anestesiologia do Departamento de Clínica, Cirurgia e Reprodução Animal da Faculdade de Medicina Veterinária e Odontologia de Araçatuba, UNESP. O programa foi credenciado pela CAPES, desde a sua criação em 1994, no Curso de Mestrado, que deve ser concluído em dois anos, e o de Doutorado, que deve ser concluído em três anos. Atualmente, após algumas reformulações, o Programa está sendo desenvolvido nos Cursos de Mestrado e Doutorado em três Áreas de Concentração: Risco e Proteção de Órgãos e Sistemas em Anestesia e Cirurgia; Qualidade e Segurança em Anestesiologia; e Modelos Clínicos e Experimentais em Terapia Antálgica, com as suas respectivas linhas de pesquisas, que são em número de quatorze (Quadro I). Na elaboração e definição do elenco de disciplinas, foram levada, fundamentalmente em consideração as linhas de pesquisa dos docentes participantes do Programa, de modo a possibilitar ao aluno contato com grupos ativamente ligados à pesquisa e ao estudo das áreas correspondentes e apresentando resultados de pesquisa publicados, de tal maneira que os conhecimentos possam ser transmitidos aos pós-graduandos do ponto de vista cultural, científico e técnico. Aestrutura curricular é constituída de 21 disciplinas das Áreas de Concentração e de nove Disciplinas do Domínio Conexo, to-

Quadro I - Áreas de Concentração com as Respectivas Linhas de Pesquisa do Programa de Pós-Graduação em Anestesiologia da UNESP

\begin{tabular}{|c|c|}
\hline Áreas de Concentração & Linhas de Pesquisa \\
\hline \multirow{5}{*}{$\begin{array}{l}\text { Risco e Proteção de Órgãos e } \\
\text { Sistemas em Anestesia e Cirurgia }\end{array}$} & Proteção renal em situações de risco durante a anestesia e cirurgia \\
\hline & Modelos para estudo dos efeitos renais de fármacos e técnicas anestésicas \\
\hline & $\begin{array}{l}\text { Reposição volêmica na hipovolemia e choque hemorrágico. Modelos experimentais em } \\
\text { Anestesiologia }\end{array}$ \\
\hline & $\begin{array}{l}\text { Modelos clínicos e experimentais para estudo dos efeitos cardiovasculares de fármacos e } \\
\text { técnicas anestésicas durante a cirurgia }\end{array}$ \\
\hline & $\begin{array}{l}\text { Modelos clínicos e experimentais para estudo das infecções pulmonares e de seu tratamento du- } \\
\text { rante ventilação artificial }\end{array}$ \\
\hline \multirow{5}{*}{$\begin{array}{l}\text { Qualidade e Segurança em } \\
\text { Anestesiologia }\end{array}$} & Modelos farmacocinéticos em anestesia venosa \\
\hline & Métodos para controle do nível de sedação e hipnose em Anestesiologia e terapia intensiva \\
\hline & $\begin{array}{l}\text { Modelos clínicos e experimentais para estudo e prevenção de efeitos nocivos relacionados aos } \\
\text { anestésicos e técnicas anestésicas }\end{array}$ \\
\hline & Avaliação da qualidade em Anestesiologia \\
\hline & Neurotoxicidade dos anestésicos locais e dos analgésicos. \\
\hline \multirow{4}{*}{$\begin{array}{l}\text { Modelos Clínicos e Experimentais em } \\
\text { Terapia Antálgica }\end{array}$} & $\begin{array}{l}\text { Dor aguda. Modelos clínicos e experimentais para estudo dos efeitos dos fármacos e técnicas } \\
\text { analgésicas }\end{array}$ \\
\hline & Dor crônica. Modelos para estudo dos efeitos dos fármacos e técnicas analgésicas \\
\hline & Interação dos anestésicos locais com drogas adjuvantes em bloqueios anestésicos regionais \\
\hline & Acupuntura: modelos analgésicos \\
\hline
\end{tabular}


das claramente vinculadas às Áreas de Concentração e às Linhas de Pesquisas, sem redundância com a formação $L$ ato Sensu. Os alunos do Programa constituído por anestesiologistas e veterinários anestesiologistas podem se inscrever na Área de Concentração em que estiver ligada a Linha de Pesquisa do projeto que será desenvolvido. O programa tem recebido alunos do Estado de São Paulo e de vários Estados do País. O programa fortalece a atividade de docência de seus alunos, ao exigir a participação de todos os pós-graduandos nas atividades de docência em cursos de graduação e de especialização da UNESP. O Programa também fortalece as atividades de pesquisa, ao exigir créditos em atividades científicas, como publicações em revistas indexadas, apresentação de pesquisas em Congressos e Jornadas, publicações em anais e aulas a convite.

O número de alunos regulares do programa aumentou nos últimos anos, tanto no Curso de Mestrado como no Doutorado (Figura 1), sendo compatível com o número de professores orientadores, com proporção média de 3 alunos para cada orientador.

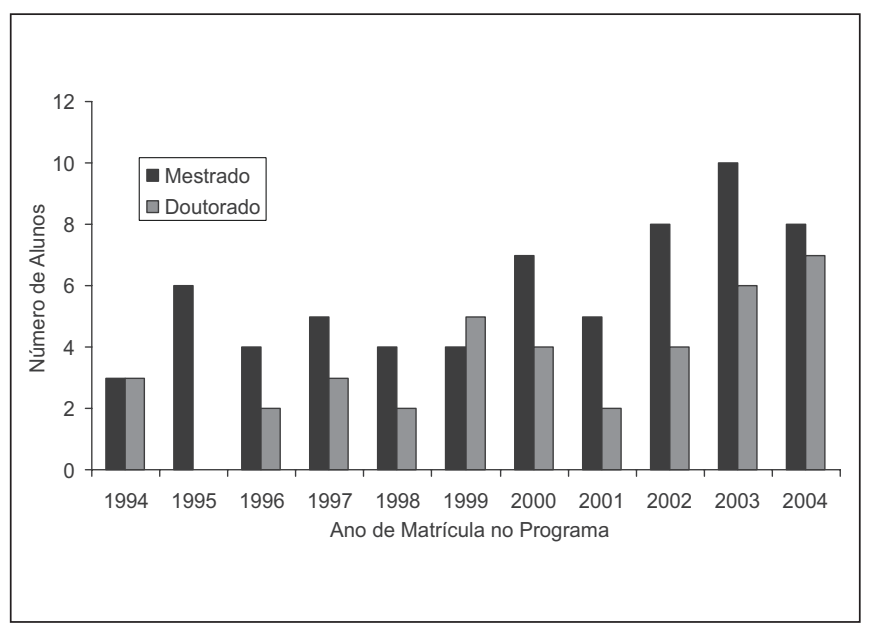

Figura 1 - Número de Alunos Regulares do Programa de Pós-Graduação em Anestesiologia da UNESP, de Acordo com o Ano de Matrícula

O número de defesas de dissertações e teses do Programa também tem aumentado nos últimos anos (Figura 2). Desde o seu início até setembro de 2004, ocorreram 45 defesas de Dissertação de Mestrado e 24 de Doutorado, perfazendo um total de 69 .

O tempo médio da titulação diminuiu expressivamente no Mestrado e Doutorado nos últimos anos (Figura 3).

As pesquisas experimentais são desenvolvidas no Laboratório de Pesquisa em Experimentação Animal do Departamento de Anestesiologia da Faculdade de Medicina de Botucatu, enquanto as pesquisas clínicas são desenvolvidas no Hospital das Clínicas da Faculdade de Medicina de Botucatu, Hospital Veterinário da Faculdade de Medicina Veterinária e Zootecnia de Botucatu e Hospital Veterinário da Faculdade de Medicina Veterinária e Odontologia de Araçatuba, SP.

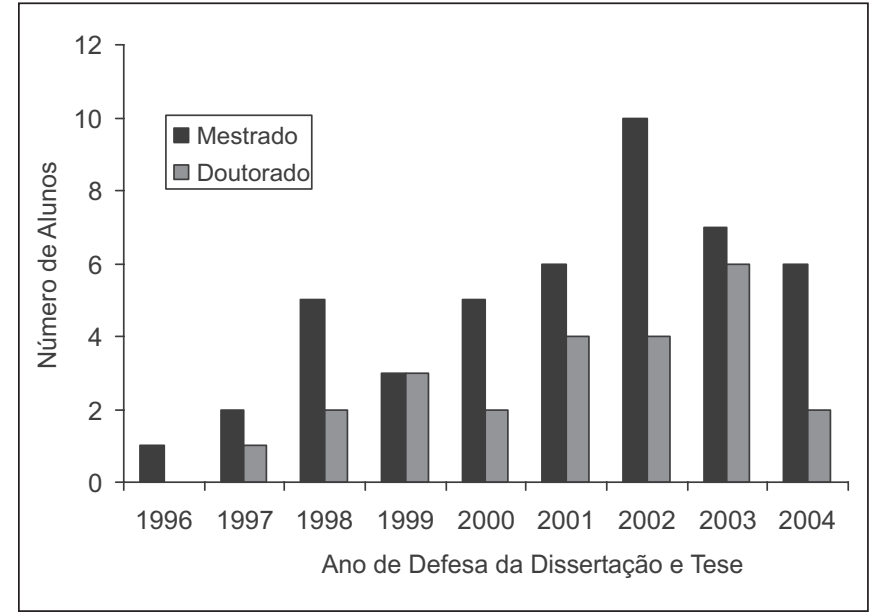

Figura 2 - Número de Defesas de Dissertações e Teses por Ano no Programa de Pós-Graduação em Anestesiologia da UNESP

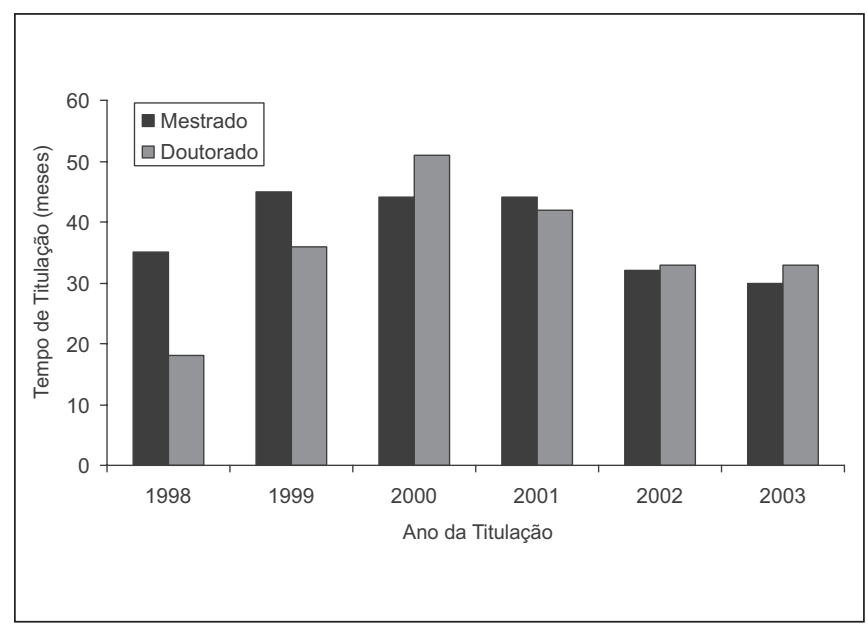

Figura 3 - Tempo de Titulação dos Pós-Graduandos no Programa de Pós-Graduação em Anestesiologia da UNESP, no Período de 1998 a 2003

Todos os projetos de pesquisa têm algum tipo de financiamento por parte dos Órgãos de Fomento do país e da UNESP e, pelo menos, $70 \%$ têm financiamento de bolsas para os pós-graduandos e para os alunos de graduação que também participam das pesquisas, promovendo uma boa integração da pós-graduação com a graduação.

O corpo docente do programa é constituído de 17 professores da UNESP em dedicação exclusiva à docência e pesquisa, com o título mínimo de doutor; dos 12 professores que participam das disciplinas e orientam os alunos, constituindo-se no núcleo principal do programa (NRD6), três são livre-docentes, cinco são professores titulares e oito realizaram doutoramento ou pós-doutoramento no exterior, o que demonstra a maturidade da docência. O processo de renovaVol. 55, No 4, Julho - Agosto, 2005 
ção docente vem se desenvolvendo com adequação, com aproveitamento de alguns egressos do Programa.

Após a conclusão do doutorado, a maioria dos alunos (65\%) tem atividade de docência em instituições públicas e privadas de ensino universitário do país. Considerando-se que a formação dos docentes na área da Anestesiologia é um dos objetivos do Programa, esse resultado confirma que um dos principais objetivos do Programa está sendo alcançado.

A maioria das publicações do Programa tem sido realizada em revistas nacionais consideradas pela CAPES como QuaIis Nacional A, sendo que algumas publicações ocorrem também em revistas internacionais com Qualis Aou B. Apesar de o número de publicações ter aumentado nos últimos anos, há necessidade do corpo discente e docente do Programa aumentar o número de suas publicações internacionais.

Em conclusão, graças aos esforços dos seus docentes e alunos, o Programa de Pós-Graduação em Anestesiologia da UNESP tem se desenvolvido muito bem, com o reconhecimento pela CAPES que, em suas últimas avaliações, tem concedido conceito 4 ao Programa, numa escala de 1 a 7 . Assim, este Programa constitui-se em alternativa importante no cenário nacional para aqueles que desejam fazer a sua pós-graduação stricto sensu em Anestesiologia.

\section{Strictu Sensu Post-Graduation in Anesthesiology: Experience of Ten Years at Universidade Estadual Paulista}

José Reinaldo Cerqueira Braz, TSA, M.D.; Pedro Thadeu Galvão Vianna, TSA M.D.; Yara Marcondes Machado Castiglia, TSA M.D.; Luiz Antonio Vane, TSA M.D.; Flávio Massone M.D.; Lino Lemonica, TSA M.D.; Gladys Bastos de Castro, M.D.

\section{INTRODUCTION}

Along the last decades, Brazilian universities have increasingly fostered strictu sensu post-graduation programs. Currently, we count on approximately 2,500 post-graduation programs, of which $35 \%$ are doctoral programs, involving approximately 100 thousand students and graduating around 5 thousand doctors a year ${ }^{1}$.

As provided in article 1 of the Resolution of Universidade Estadual Paulista (UNESP) n. 45, from $1999^{2}$, providing about General Post-Graduation Rules, UNESP's Post-Graduation aims at qualifying professors, investigators and human resources specialized in different fields of knowledge, as well as at developing scientific and technological areas.

There are currently in Brazil two strictu sensu Post-Graduation Programs in Anesthesiology, both in the State of São Paulo - the first from the School of Medicine, Universidade de São Paulo (USP), São Paulo and more recently the second, from UNESP, School of Medicine, Botucatu. Other strictu sensu Post-Graduation programs, in general for surgical areas, also have research lines in Anesthesiology, which allows anesthesiologists to also attend such programs and carry out research in Anesthesiology.

Aiming at fostering strictu sensu post-graduation programs in Anesthesiology in Brazil, we present a post-graduation program and its cumulative experience after 10 years of activity.

\section{POST-GRADUATION PROGRAM IN ANESTHESIOLOGY - UNESP}

The strictu sensu program in Anesthesiology - UNESP, after the approval of the Coordination of Graduated Personnel Improvement (CAPES), has started its activities in August 1994 , with the aim of qualifying researchers and professors in Anesthesiology and is opened to physicians and veterinarians specialized in Anesthesiology.

The program was developed across UNESP departments and units and has initially involved the Department of Anesthesiology, School of Medicine, Botucatu and the Veterinary Surgery and Anesthesiology Department of the School of Veterinary Medicine and Zoology. Soon after, other Departments of the School of Medicine and Biosciences, Botucatu and of the Discipline of Anesthesiology of the Department of Clinic, Surgery and Animal Reproduction, School of Veterinary Medicine and Dentistry, Araçatuba, UNESP were also involved. The program was accredited by CAPES since its beginning in 1994 for Master programs to be concluded within two years and Doctoral programs to be concluded within three years.

Currently, after some reformulations, Master and Doctoral Programs are being developed within three fields of study: Organs and Systems Risk and Protection in Anesthesia and Surgery; Quality and Safety in Anesthesiology; and Clinical and Experimental Models for Pain Therapy, with their respective 14 research lines (Chart I).

In preparing and defining the disciplines, research lines of faculties participating in the Program were fundamentally taken into consideration to expose students to groups actively involved with research and with the study of corresponding areas and presenting published results in a way that knowledge may be culturally, scientifically and technically transmitted to students.

The curriculum is made up of 21 disciplines within the fields of study and of 9 Connected Domain disciplines, all clearly linked to the fields of study and research lines, without redundancy with Lato Sensu programs. Students, represented by anesthesiologists and veterinarian anesthesiologists, may enroll in the field of study to which the research line of the project to be developed is related. The program has received students from the State of São Paulo and other Brazilian States. The program strengthens teaching activities of its students by requiring their participation in teaching activities of UNESP graduation and specialization programs. The program also strengthens research activities by requiring credits in scientific activities, such as publications in indexed jour- 
Organs and Systems Risk and Protection in Anesthesia and Surgery
Volume replacement during hypovolemia and hemorrhagic shock. Experimental models in Anesthesiology

Clinical and experimental models to evaluate cardiovascular effects of drugs and anesthetic techniques during surgery

Clinical and experimental models to evaluate pulmonary infections and their treatment during artificial ventilation.

\section{Pharmacokinetic models for intravenous anesthesia}

Methods to control sedation and hypnosis in Anesthesiology and Intensive Care Unit

Quality and Safety in Anesthesiology

Clinical and experimental models to evaluate and prevent noxious effects related to anesthetic drugs and techniques.

Evaluation of quality in Anesthesiology

Neurotoxicity of local anesthetics and analgesics

Acute pain. Clinical and experimental models to evaluate the effects of drugs and analgesic techniques

Chronic pain. Models to evaluate the effects of drugs and analgesic techniques

Clinical and Experimental Models for Pain Therapy
Interaction of local anesthetics and adjuvant drugs during regional anesthetic blocks

Acupuncture: analgesic models nals, presentation of studies during Congresses and Journeys, publications in Year Books, and teaching as guest professors.

The number of regular students has increased in recent years both for Master and Doctoral programs (Figure 1) being compatible with the number of faculty advisers: in average 3 students per adviser.

The number of theses and reports has also increased in recent years (Figure 2). From its beginning until September 2004 , there were 45 Master and 24 Doctoral reports, in a total of 69 .

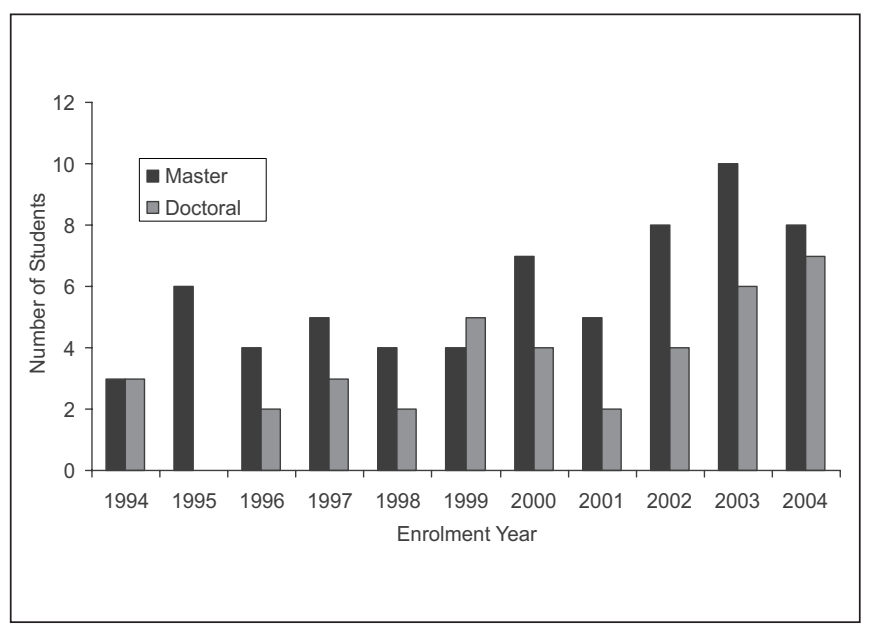

Figure 1 - Regular Students of the Post-Graduation Program in Anesthesiology, UNESP, according to the year of enrolment

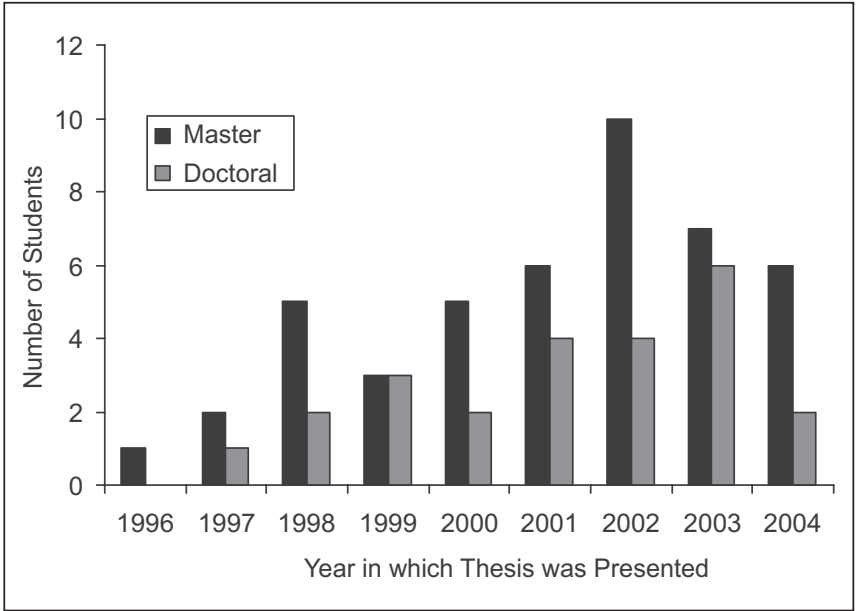

Figure 2 - Number of Reports and Theses per Year of the Post-Graduation Program in Anesthesiology - UNESP

Mean graduation time has significantly decreased for Master and Doctoral programs in recent years (Figure 3 ).

Experimental studies are developed in The Animal Experiment Research Laboratory, Department of Anesthesiology, School of Medicine, Botucatu, while clinical studies are developed in the Hospital das Clínicas, School of Medicine, Botucatu, Veterinary Hospital, School of Veterinary Medicine and Zootechny, Botucatu and Veterinary Hospital, School of Veterinary Medicine and Dentistry, Araçatuba, SP.

All projects have some type of funding from Brazilian Fostering Agencies and UNESP, and at least $70 \%$ have scholarships for post-graduating and graduating students participat- 


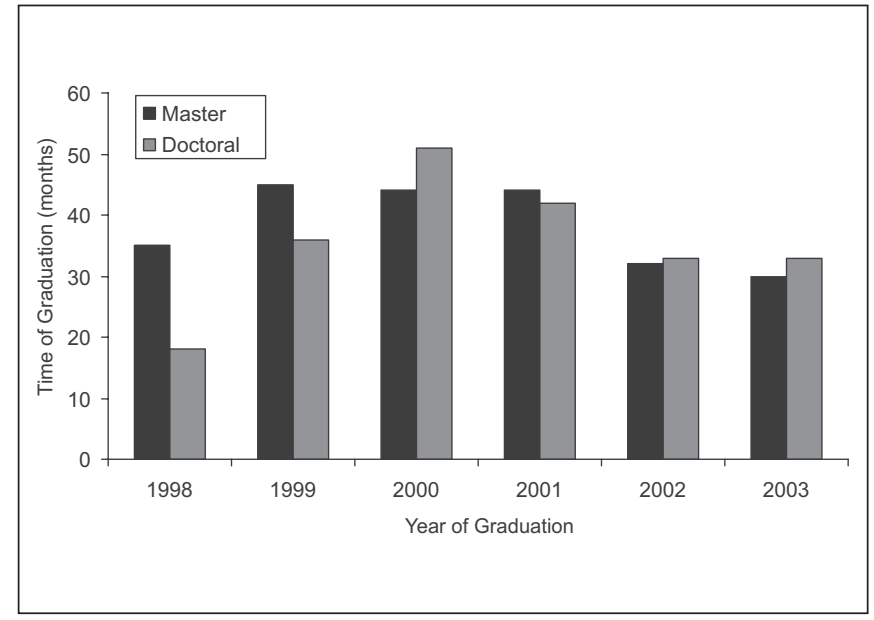

Figure 3 - Time to Graduate in the Post-Graduation Program in Anesthesiology - UNESP, in the Period 1998 to 2003

ing in the researches, promoting a successful integration between post-graduation and graduation programs.

Faculty members are represented by 17 UNESP professors full-time dedicated to teaching and researching, with minimum title of doctor (PLD); from 12 professors participating in the disciplines and advising students, and representing major program core (NRD6), three are full professors, five are head professors and eight have completed their master or doctoral programs abroad, reflecting the seniority of faculty members. Professors are adequately renewed and some former students are invited to teach.

After completing the doctoral program, most students (65\%) dedicate themselves to teaching in Brazilian public and private universities. Considering that qualifying professors in Anesthesiology is a Program's goal, this result confirms that one of the major objectives of the Program is being reached.

Most program studies are published in Brazilian journals considered by CAPES as National Qualis A, and some are published in international Qualis A or B journals. Although the number of publications has increased in recent years, students and professors still have to increase the number of international publications.

In conclusion, thanks to the efforts of its students and professors, UNESP Post-Graduation Program in Anesthesiology is successfully evolving and this has been recognized by CAPES, which in its recent evaluations has graded the Program 4, in a scale from 1 to 7 . So, this Program is a major alternative in Brazil for those wishing to complete a strictu sensu post-graduation program in Anesthesiology.

\section{REFERÊNCIAS - REFERENCES}

01. Velloso J - Formação no país ou no exterior? Doutores na pós-graduação de excelência. Brasília: Fundação Coordenação de Aperfeiçoamento de Pessoal de Nível Superior, 2002;260.

02. UNESP - Regimento Geral de Pós-Graduação. Pró-Reitoria da Pós-Graduação e Pesquisa, 1999;20.

\section{RESUMEN}

Braz JRC, Vianna PTG, Castiglia YMM, Vane La, Massone F, Lemonica L, Castro GB - Pos-Graduación Stricto Sensu en Anestesiología: Experiencia de Diez Años en la UNESP

JUSTIFICATIVA Y OBJETIVOS: El número de Programas de Pos-graduación en Anestesiología stricto sensu existente en el país aún es muy pequeño. Con la finalidad de incentivar la pos-graduación en Anestesiología en Brasil, se presenta la experiencia acumulada en diez años de actividades del programa de la Universidad Estadual Paulista (UNESP).

CONTENIDO: El Programa de Pos-graduación en Anestesiología stricto sensu de la UNESP fue credenciado por la CAPES, desde su creación en 1994, en los Cursos de Maestrado y Doctorado. El Programa es desarrollado en tres Áreas de Concentración: Riesgo y Protección de Órganos y Sistemas en Anestesia y Cirugía; Calidad y Seguridad en Anestesiología y Modelos Clínicos y Experimentales en Terapia Antálgica, con sus respectivas líneas de pesquisa, en número de 14. El número de alumnos regulares del Programa es compatible con el número de orientadores (12), con proporción media de tres alumnos por orientador. Desde su inicio hasta septiembre de 2004, ocurrieron 45 Disertaciones de Maestrado y 24 de Doctorado, completando el número de 69 defensas, la mayoría con bolsas y financiaciones de Órganos de Fomento a la Pesquisa. Después de la conclusión del doctorado, $65 \%$ de los alumnos tienen actividad de docencia y pesquisa en instituciones públicas y privadas de la enseñanza universitaria del país. La mayoría de las publicaciones del programa ha sido realizada en revistas nacionales con Qualis $A$, con menor número de publicaciones en revistas internacionales Qualis A o B. El programa recibió de la CAPES el concepto 4,0 en una escala de 1 a 7 , en sus tres últimas evaluaciones.

CONCLUSIONES: El programa se desarrolló muy bien en los 10 años de su existencia, con los principales objetivos siendo alcanzados, como la formación de profesores y pesquisadores en la área de Anestesiología para las instituciones universitarias del país. 